\title{
Geological observations in the Five-Klippes area, northwestern Katanga Copperbelt (Democratic Republic of the Congo)
}

\author{
MAURICE ILUNGA YANTAMBWE ${ }^{1} \&$ JACQUES L.H. CAILTEUX $2^{2 *}$
}

\author{
${ }^{1}$ Bankers Cobalt Mining, Av. Kisambi, 7692A, Lubumbashi,D.R.Congo; maurilunga@gmail.com. \\ ${ }^{2}$ Royal Museum for Central Africa, Geodynamics and Mineral Resources, Leuvensesteenweg 13, B-3080 Tervuren, Belgium; \\ jcailteux.geol@gmail.com. \\ "corresponding author.
}

\begin{abstract}
Surface mapping and exploration in the search license PR-2348, northwest of Kolwezi in the Neoproterozoic Katanga Copperbelt, focussed in the poorly documented Five-Klippes area, and showed that the Roan megabreccias occurring at the ground surface in the klippes are composed mostly of Musonoï, Mines (Kamoto Formation) and Kiubo rocks that form km- to mm-size blocks, fragments and matrix. The megabreccias are bordered by rocks of the Kiubo Formation, that are gently dipping south on the northern side, with few approximatively $10 \mathrm{~m}$-size sharp refolding close to the megabreccia, while they are vertically dipping north on the southern side. A $262 \mathrm{~m}$-long exploration core drilling performed under the megabreccia of one of the klippes highlighted a faulting marked by hydraulic-like fractured-deformed Kiubo rocks and by friction breccias. The Kiubo blocks, fragments and matrix in the megabreccia were teared out most likely from the southern limb of the fault. The faulting in depth is interpreted here as the roots of the ground surface megabreccia. This rupture and shearing is questioning the autochthonous character of the surrounding Kiubo and Mongwe rocks. It is suggested that, similarly as for the eastern Mamfwe anticline, the Nguba and Kundelungu groups succession in the klippes area constituted blocks thrust during the fold-and-thrust event of the Katangan orogeny, and extruded the megabreccias of the klippes before suture during the final stage of the northward compression. A nearly north-south transversal faulting and shearing crosscutting the limbs and megabreccias of the klippes marked the end of the compression. These new observations complement other similar ones in that region, and have important implications for future $\mathrm{Cu}-\mathrm{Co}$ exploration.
\end{abstract}

KEYWORDS: Neoproterozoic, Katanga Supergroup, Kolwezi region, lithologic and structural setting.

\section{Introduction}

The Vale Group, through the Vale-RDC Company, operated in 2010-2012 surface and drilling explorations in the search licence PR-2348, in the northwestern portion of the Katanga Copperbelt (here after KCB), in the Democratic Republic of the Congo (here after "Congo") (Figs 1,2). This permit, nearly $20 \mathrm{~km}$ north-northeast of Kolwezi, includes the poorly documented Five-Klippes area that displays Roan megabreccias and was expected to possibly contain economic copper and cobalt occurrences. Exploration for $\mathrm{Cu}-\mathrm{Co}$ on that area provided new geological observations, especially on the structural setting of the megabreccias.

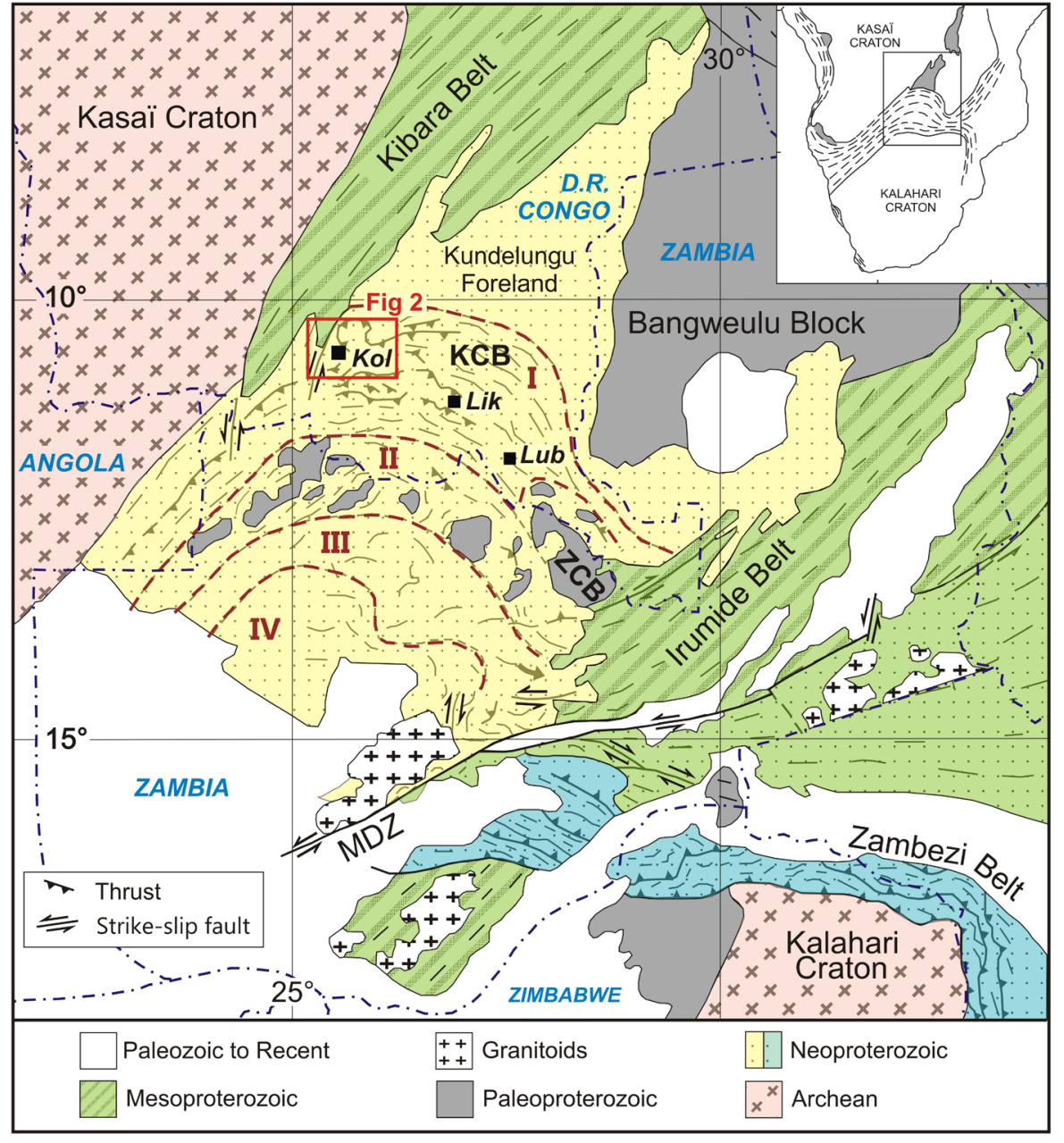

Figure 1. Geological and tectonic map of the Lufilian Arc with its I to IV structural subdivisions, the Kundelungu Foreland and the Paleo-Mesoproterozoic basement (modified after Kampunzu \& Cailteux, 1999). KCB = Katanga Copperbelt; ZCB = Zambia Copperbelt; MDZ = Mwembeshi Dislocation Zone. I = External fold and thrust belt; II = Domes region; III = Synclinorial belt; IV = Katanga high; $L u b=$ Lubumbashi; $L i k=$ Likasi; Kol $=$ Kolwezi. Position of Fig. 2. 

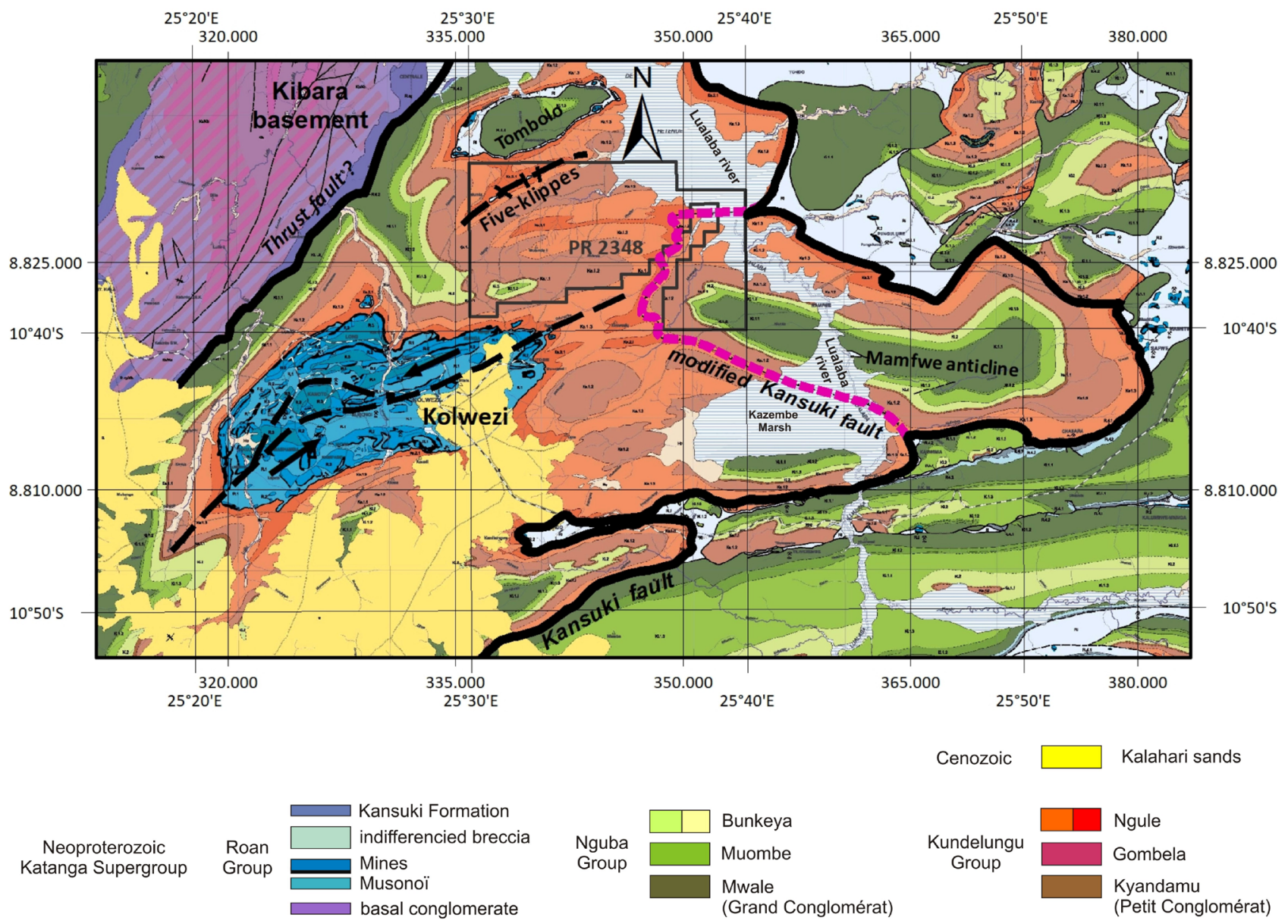

Cenozoic

Kalahari sands

Paleo \&
Mesoproterozoic

Kibara basement

Figure 2. Geological map of the northwestern part of the KCB, locating the Kolwezi, Five-Klippes and Tombolo megabreccias (modified after François, 1973, 2006); position of the major thrust faults, of the Mamfwe anticline, and of the search licence PR-2348 that includes the Five-Klippes area; modified Kansuki fault according to François (2006). The former Ks21 and Ks13 correspond to the Kiubo and Mongwe units, respectively, and Ks12 to the Gombela Subgroup (Cailteux \& De Putter, 2019).

The Neoproterozoic Katangan rocks were intensely folded during the pan-African Lufilian orogeny and formed large thrust nappes in the central and southern parts of the KCB (François, 1987, 2006). Contrastingly, the outcropping Nguba and Kundelungu rocks in the northwestern part are interpreted as autochthonous Katangan, the so-called "autochthonous massif" (François, 1973). It is overlain by the Kolwezi, Five-Klippes and Tombolo allochthonous thrust nappes, mostly composed of polymictic breccias that the same author interpreted as extruded from the Kansuki fault occurring to the south. However, recent observations in Kolwezi and in the Mamfwe anticline questioned the autochthonous character of the Nguba and Kundelungu groups succession in that area (Cailteux, 1991; Cailteux in François, 1994). Moreover, the modified border of the autochthonous massif at the thrust contact with the Mamfwe anticline (Fig. 2) as interpreted by François (1994) is not really convincing. The objective of this study is to present the lithologic and structural results from this recent exploration in the Five-Klippes area. The results represent a valuable contribution to better understand the geology in this northwestern region of the $\mathrm{KCB}$, especially in the autochthonous-allochthonous discussion, and have implications for future $\mathrm{Cu}-\mathrm{Co}$ exploration.

\section{Geological setting}

The Neoproterozoic KCB forms a north-directed convex thrust-and-fold belt, called "the Lufilian arc", resulting from the convergence of the Kasaï and Kalahari cratons during the pan-African Lufilian orogeny (Coward \& Daly, 1984; Kampunzu et al., 1991; Cosy et al., 1992; Kampunzu \& Cailteux, 1999). It is characterized by folding and thrusting of the Katangan rocks, leading to nappe emplacement pushed to the north (Kampunzu \& Cailteux, 1999; Kipata et al., 2013).

The Katanga Supergroup is subdivided into three sedimentary units, from bottom to top: the Roan, Nguba and Kundelungu groups (Table 1). This subdivision is based on the occurrence of two diamictites, the Mwale ("Grand Conglomérat") Subgroup at the base of the Nguba Group, and the Kyandamu ("Petit Conglomérat") Subgroup at the base of the Kundelungu Group (François, 1987; Batumike et al., 2007; Cailteux et al., 2007; Cailteux \& De Putter, 2019). The basal Roan Group comprises from bottom to top the Musonoï (former R.A.T. "Roches ArgiloTalqueuses"), Mines, Fungurume (former Dipeta), and Mwashya subgroups (Table 1). The upper part of the Kundelungu Group comprises the mostly pelitic Mongwe Formation succeeded by the mostly sandy Kiubo Formation at the top (Table 1), both being characterized by alternating pelites, sandy pelites, sandstones and arkosic sandstones, with a variable carbonate content (François, 1973). These formations are interpreted as molasse deposits filling the Kundelungu basin (François, 1973; Batumike et al., 2007). The top of the Kiubo Formation is marked by a major tectonic unconformity representing the basal thrust-faults of the nappes, and is locally overlain by the megabreccias that form the base of the nappes (Cailteux et al., 2018).

The Roan Group is affected by several major tectonic discontinuities (i.e. at the base and at the top of the Musonoï, Mines, and within the Fungurume subgroups). It occurs as up to km-size large (here below called "blocks") and smaller fragments in the megabreccias as a result from folding, fracturing and thrusting (Cailteux, 1994; Cailteux \& Kampunzu, 1995). The well-known sediment-hosted stratiform, hydrothermalsynorogenic-enriched $\mathrm{Cu}-\mathrm{Co}$ mineralisation is mostly hosted in blocks and fragments of the Mines Subgroup (Cailteux et al., 2005; El Desouky et al., 2010). 


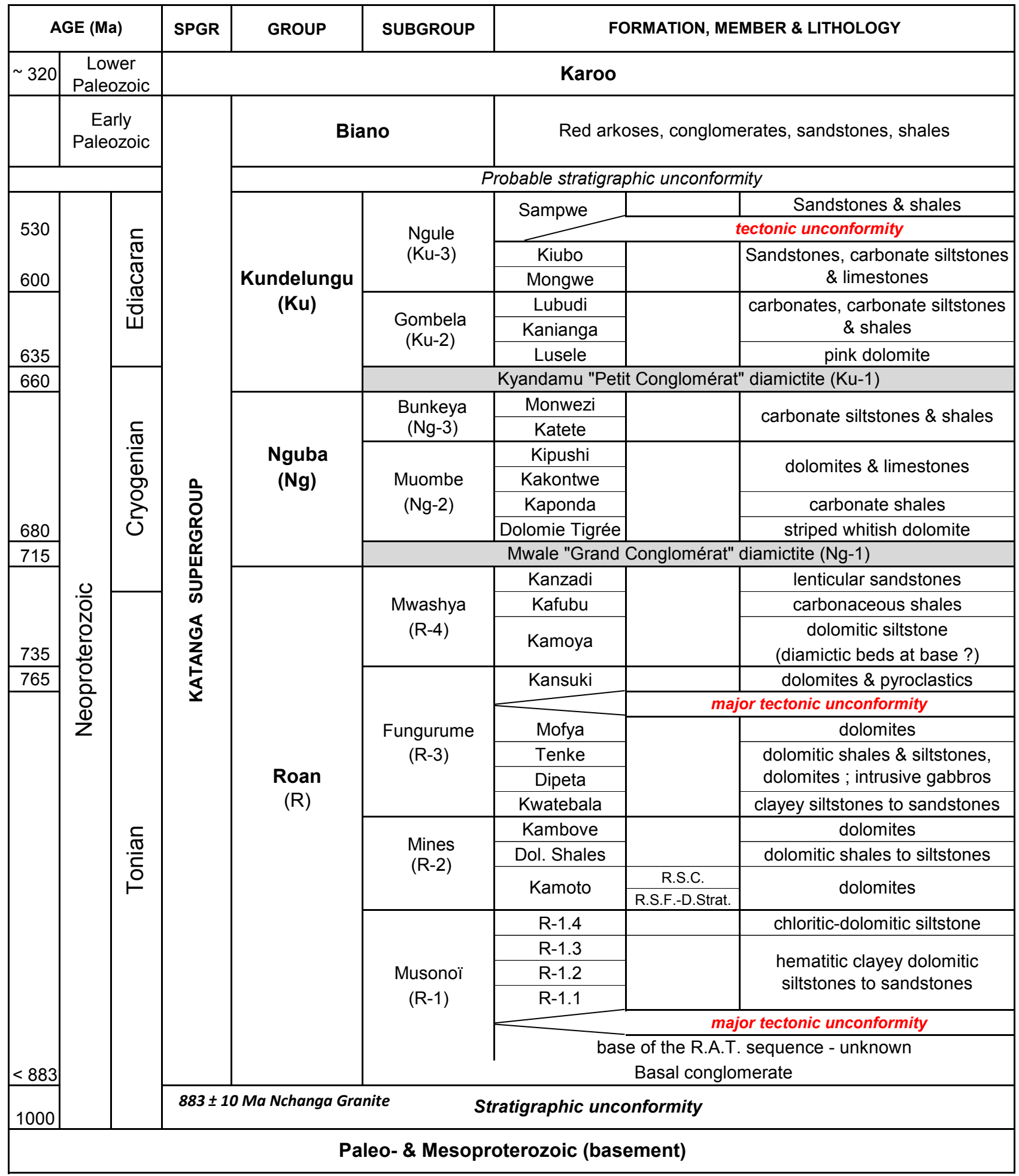

Table 1. Lithostratigraphy of the Katanga Supergroup in the KCB (according to Cailteux \& De Putter, 2019).

Formation of the megabreccias resulted, through compression, from brittle fracturing after folding, hydraulic fracturing by liberation of the fluids and subsequent fragmentation of the rocks, ductile shearing, friction and abrasion of the fragments, and precipitation of carbonate in the voids after decompression (Cailteux et al., 2018). The importance of the expelled ambient high salinity fluids increased by an addition of low salinity most likely meteoritic water, and by subsequent dissolution of some evaporites contained within the sedimentary pile. These fluids contributed to fluidization of the breccias and facilitated the pinching out of megabreccias (extrusion-like) along thrust-faults (Cailteux et al., 2018).

In the northwestern portion of the KCB, the Kolwezi, FiveKlippes and Tombolo megabreccias are composed of blocks from the Roan, Nguba and Kundelungu groups embedded in breccias containing smaller size fragments and brecciated rocks derived from the same lithologies (François, 1973). According to François $(1973,1987)$, these megabreccias were deposited in the centre of basins everywhere surrounded by gently dipping autochthonous Mongwe and Kiubo units, and are relics of a unique thrust nappe extruded from the SW-NE oriented southern portion of the Kansuki fault (Fig. 2). The latter is also interpreted as forming the eastern and northern borders of the autochthonous massif. Rocks of the Paleo-Mesoproterozoic basement, that are bordering the $\mathrm{KCB}$ to the west, are uncomformably overlain by a transgressive basal conglomerate. Formations overlying this conglomerate along the basement are the Mwale (Grand Conglomérat) to the southeast, and Mwashya or undistinguished Roan rocks to the northwest and to the south (François, 1973, 1995 Kennedy et al., 2019). 


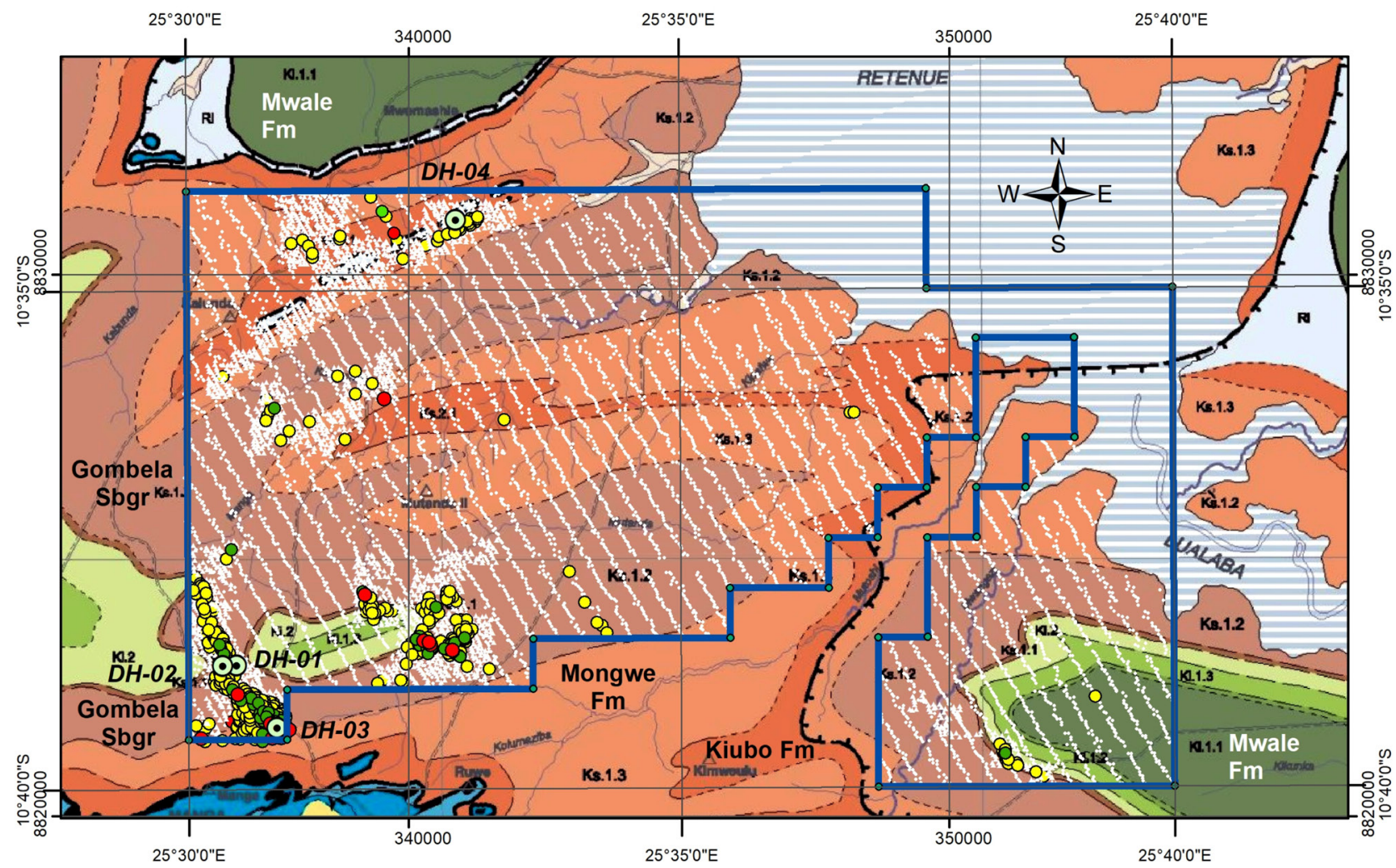

Figure 3. Geochemical results from the 2010 and 2011 exploration campaigns on the geological map. Spots in white $=0-99$ ppm; yellow $=100-199$ ppm; green $=200-299 \mathrm{ppm}$; red $=>300 \mathrm{ppm}$. Position of the four drill holes (DH-01 to DH-04).

Recent observations questioning the autochthonous massif in that region showed that: (1) the Mamfwe anticline, eastern portion of the autochthonous massif (Fig. 2), is a slice of Nguba and Kundelungu rocks thrust over the Kiubo Formation that occurs at $\sim 890$ m-depth under a $\sim 310$ m-thick polymictic breccia (Cailteux 1991); and (2) ruptures of the Kiubo Formation observed in mine galleries under the megabreccia at Kolwezi, marked by faults, subvertical dips, and up to several hundred m-thick mostly monomictic breccias of Kundelungu rocks that can represent roots of the Kolwezi megabreccia (Cailteux, in François, 1994).

\section{Geochemical exploration}

\subsection{Methodology}

Search for metallic mineralisation was based on a surface geochemical sampling undertaken on a $400 \mathrm{~m}$ line by $50 \mathrm{~m}$ spacing in 2010 and on a complementary $100 \mathrm{~m}$ line by $50 \mathrm{~m}$ spacing in 2011, covering $95 \%$ of the licence and especially the Five-Klippes area (Figs 2, 3). A total of 9337 termite mound and subsurface collected samples were used (6721 from 2010 and 2616 from 2011 sampling). All samples were analysed by ICPMS at the ALS Chemex facility in South Africa.

\subsection{Results}

The geochemical results of both the 2010 and 2011 exploration campaigns indicated six distinct $\mathrm{Cu}(-\mathrm{Co})$ bearing anomalies in the permit area (Fig. 3). Among these, two notable anomalies are located in the southwest corner of the permit, on the Kanianga Formation (Gombela Subgroup; Table 1). Despite these two anomalies (one $\mathrm{Cu}-\mathrm{Co}$ at the extreme southwest, the other one only copper-bearing) are partly based on termite mound samples, predating the anthropological activities, a contamination by miners cannot be excluded in that northeastern area of the Kolwezi nappe. Two identified lower copper-bearing anomalies are located one more to the north showing dispersed values on the Kanianga and Mongwe lithologies, and the second one at the extreme southeast of the permit on Monwezi lithologies (Fig. 3; Table 1). The two last anomalies are located in the Five-Klippes area, one along the southern border of the Klippe- 2 megabreccia near the DH-04, and the second one showing values with a northwest-southeast orientation most probably related to the transverse faults between Klippes-3, -4 and -5 (see $\$ 5$ below).

\section{Geology of the Five-Klippes}

\subsection{Methodology}

Structural and lithologic characterization of the Five-Klippes is based on: (1) surface mapping including description of 9 trenches crossing the klippes, 23 pits and observations on outcrops (Figs 4, 5); and (2) the geological logging of a $262 \mathrm{~m}$-long core drilling (DH-04) oriented at $150^{\circ} \mathrm{NE}$ with a dip of $60^{\circ} \mathrm{SE}$, performed from the northern margin of Klippe-2 (Figs 3, 4, 6) in order to verify in depth the geochemical anomaly occurring along the southern border of this klippe.

\subsection{Lithologic setting}

\subsubsection{Kiubo Formation}

In the Five-Klippes area, the Mongwe and Kiubo units typically consist of alternating carbonate bearing pelitic shales, sandy pelites, sandstones and arkosic sandstones, predominantly pelitic marine in the lower part (Mongwe), and predominantly sandy shallow-water in the upper part (Kiubo). The beds are characterized by frequent $\mathrm{cm}$-scale chaotic internal slumps, microfolding, and intraclastic conglomerates consisting of red shale pellets within sandstone. Sandstones of the Kiubo Formation are marked by coarse-grained arkosic layers, crossbedding or ripple-marks. The sandstones alternate with minor sericitic-chloritic shale or siltstone beds. Carbonate sandy to arkosic sandstone 1 to $5 \mathrm{~m}$-thick beds with rounded cherts, that are markers of the Kiubo Formation (François, 1973, 1987), were observed in trenches at the northern side of Klippes 1, 2 and 3, and at the southern side of Klippe 5 .

\subsubsection{Megabreccias of the klippes}

The klippes are formed by megabreccias containing: $(1)<1 \mathrm{~m}$-size up to $\mathrm{km}$-size fragments and blocks mostly of the Musonoï and 


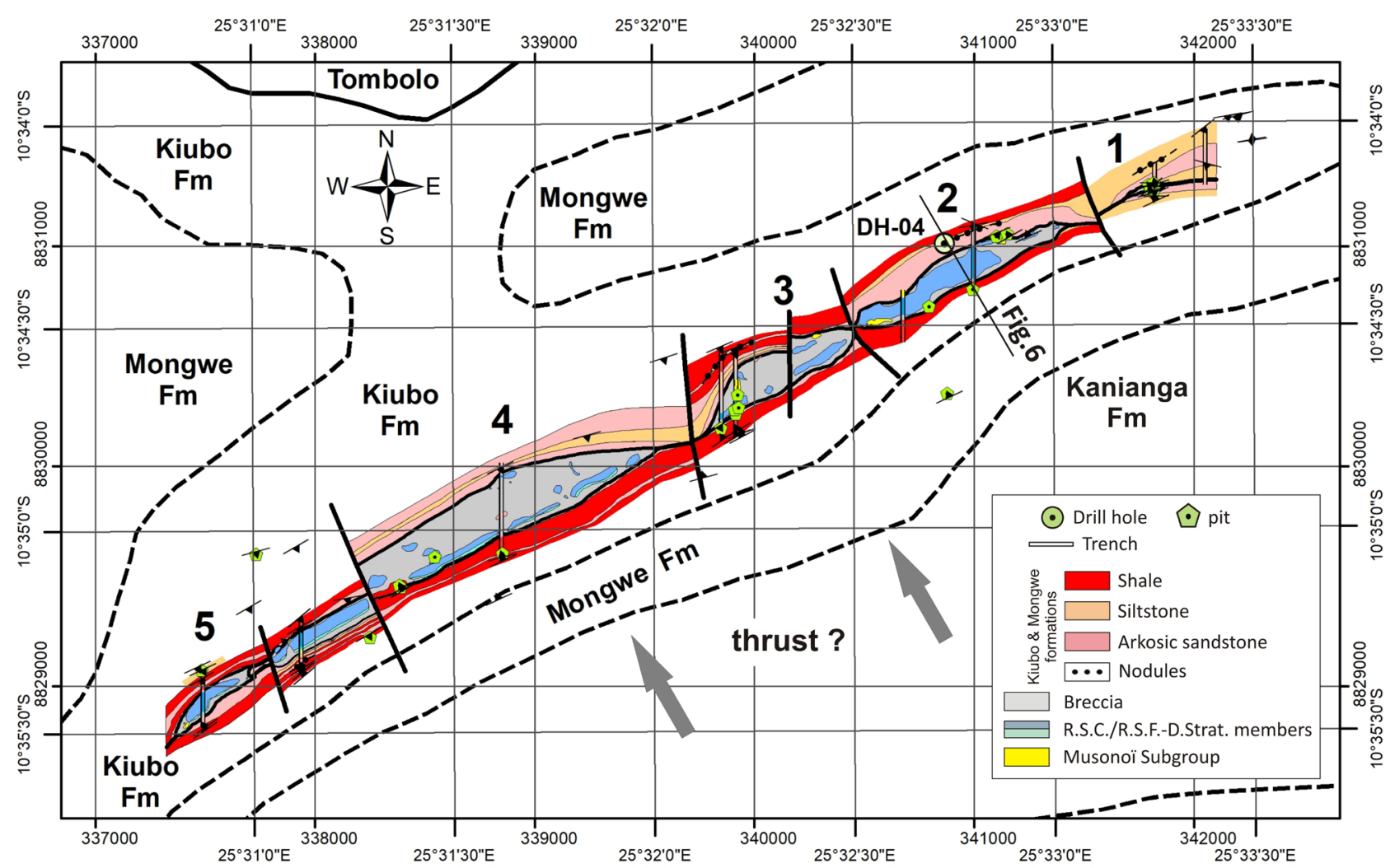

Figure 4. Detailed geological map of the Five-Klippes area, with location of the drill hole DH-04, pits and trenches. Regional geological background after François $(1973,2006)$. Fm = Formation. Position of Fig. 6.

Mines subgroups, and of the Kiubo Formation (Fig. 4); and (2) monomictic or polymictic breccias composed of mm- to dm-size fragments of the same material that occur as a matrix between the blocks and fragments. The megabreccias of the klippes are bordered variably on both sides by arkosic sandstones, siltstones and pelitic shales of the Kiubo Formation. They form hills raising 30 to $50 \mathrm{~m}$-high marked by carbonate-siliceous rocks of the Mines Subgroup and megabreccia at the top (Fig. 5A, 5B). Weathering is marked by: (1) alteration into clay of the pelitic material of the Kiubo Formation; (2) alteration into talc and clay of the muddy dolomitic Musonoï rocks; (3) dissolution of the carbonate in the Kiubo Formation, polymictic breccias, variably brecciated Musonoï rocks and Mines fragments; and (4) oxidation and hydration of the sulphide minerals giving way to development of goethite and limonite impregnation. The thickness of the weathered zone is not well constrained, reaching up to several dozen metres. In the drill hole DH-04, weathering has been observed up to 200 m-deep along the fractures, dissolving the carbonate and precipitating iron hydroxides and quartz in veins or cavities.

The Musonoï Subgroup mostly occurs as isolated blocs (e.g. in Klippes-2, -3, -5; Fig. 4). They are massive reddish hematitic highly weathered argillaceous talc-bearing siltstones, and show variable brecciations as commonly observed in the KCB (Cailteux et al., 2005, 2018).

The Mines Subgroup consists of strongly silicified formations of the Kamoto dolomite occurring as blocks, while the Dolomitic Shales and Kambove units have not been observed. The R.S.C. ("Roches Siliceuses Cellulaires") member mostly occurs accompanied in Klippes-4 and -5 by the R.S.F. ("Roches Siliceuses Feuilletées") member and its basal D.Strat. ("Dolomies Stratifiées") submember (Table 1, Fig. 4). As frequently observed in the KCB: (1) the R.S.C. are massive quartzitic rocks marked by dm-size stromatolites (Fig. 5G), voids and cavities; (2) the R.S.F. are finely laminated-banded rocks showing alternating coarse- to fine-grained quartz or chert with more siliceous to more chloriticsericitic bands in the upper part (R.S.F. s.s.), and thicker bedded rocks in the lower part (D.Strat.) with typical cherty oncolitic nodules near the contact with the upper R.S.F. Constituent minerals are predominantly quartz and chert, with minor chloritesericite/clay minerals. Chlorite and sericite has been strongly altered into clay minerals that were impregnated by limonite. Indication of schistosity within D.Strat.-R.S.F. chloritic-sericitic micro-band sequences suggests tectonic deformation. Goethitehematite most likely originates from pyrite oxidation.

The Kiubo Formation consists of blocks and m-size fragments mostly of arkosic sandstones detached from the Kiubo borders of the megabreccia.

Polymictic breccias occurring between the blocks contain variable Musonoï, Mines and Kiubo material as $\mathrm{mm}$ - to $\mathrm{cm}$-size fragments and matrix (Figs 5C, 5D, 5E, 5F). Breccias in Klippes 4 and 5 predominantly contain arkosic sandstone fragments and matrix of the Kiubo Formation; they mostly consist of Musonoi material in Klippe-3, while arkosic sandstone (Kiubo Formation) and Musonoï material are nearly equally occurring in Klippe-2. Breccias with (Kiubo) arkosic sandstone fragments and matrix most likely occur along both margins of the megabreccia, while breccias containing siliceous R.S.C. and R.S.F.-D.Strat. fragments most frequently occur close to the Mines blocks. At the ground surface, these breccias show: (1) a strong weatheringrelated oxidation and hydration with the development of goethite and limonite; (2) voids probably related to the leaching out of carbonate and/or anhydrite minerals, and their possible infilling by clay minerals.

\subsection{Structural setting}

The five klippes form a $\sim 60^{\circ} \mathrm{NE}$ oriented elongate structure, extending $\sim 5.5 \mathrm{~km}$. They are surrounded by alternating sandstones, siltstones and shales of the Kiubo Formation, trending mostly in the range $\mathrm{N} 50^{\circ}-80^{\circ} \mathrm{E}$ (Figs 2, 4).

On the northern side of the klippes, the Kiubo-Mongwe sequence is gently dipping to the south (mostly in the range from $6^{\circ}$ to $35^{\circ}$ ). Locally, sharp $\sim 10 \mathrm{~m}$-size refolding have been observed close to the margin of the klippes (e.g. along Klippes-2 and -5 ), with dips quickly changing in the range from $35^{\circ}$ to $70^{\circ}$. By contrast, the beds on the southern side show more vertical dips in the range from $50^{\circ}$ to $90^{\circ}$ (e.g. Fig. 6). Subvertical dips most likely are observed close to the megabreccia.

The Kiubo rocks are strongly fractured and brecciated at the contact with the megabreccia, and fault faces with striations are observed within sandstone beds at the southern side of Klippe-1. 

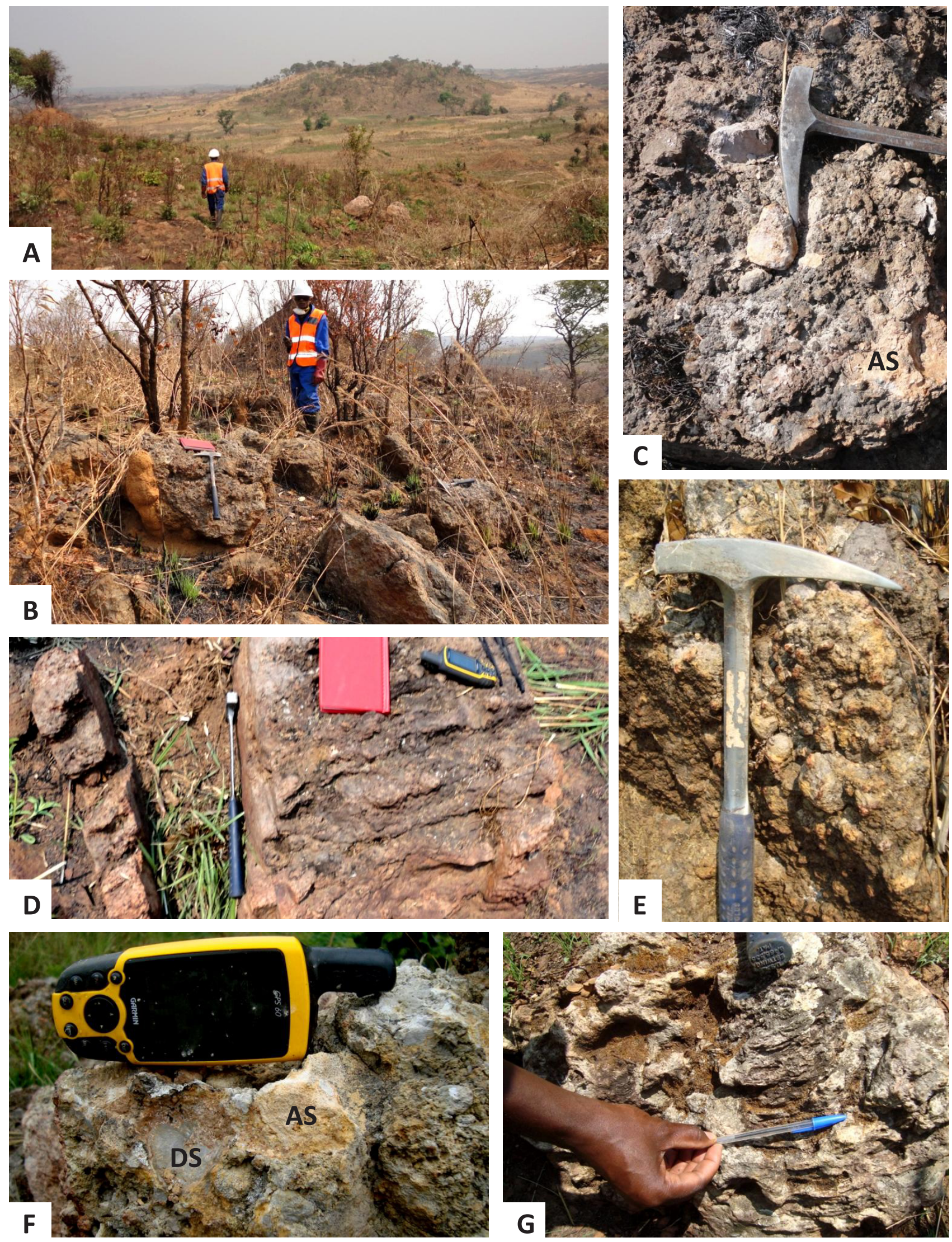

Figure 5. A: Sight of Klippe-2 from Klippe-1, both forming hills raising 30-50 m-high. B: polymictic breccia at the top of the Klippe-4 hill showing predominant arkosic sandstone fragments and matrix of the Kiubo Formation and from the Musonoï (former R.A.T.) Subgroup. C: Monomictic to polymictic breccia in Klippe-2 showing fragments and matrix from the Musonoï Subgroup and a few fragments from the Kiubo Formation (AS = arkosic sandstone). D: Polymictic breccia in Klippe-3 hill showing predominant fragments and matrix from the Musonoï Subgroup and minor from the Kiubo Formation; evidence of late subvertical fracturing through the breccia. E: Polymictic breccia in Klippe-2 showing fragments and matrix from both the Kiubo Formation and the Musonoï Subgroup. F: Polymictic breccia in Klippe-1 showing cm-size arkosic sandstone (AS) and silicified dolomite (DS) fragments from the Kiubo Formation and probably the R.S.C. member, respectively. G: Fragment from the R.S.C. member in the megabreccia of Klippe-5 showing siliceous relics of stromatolites. 


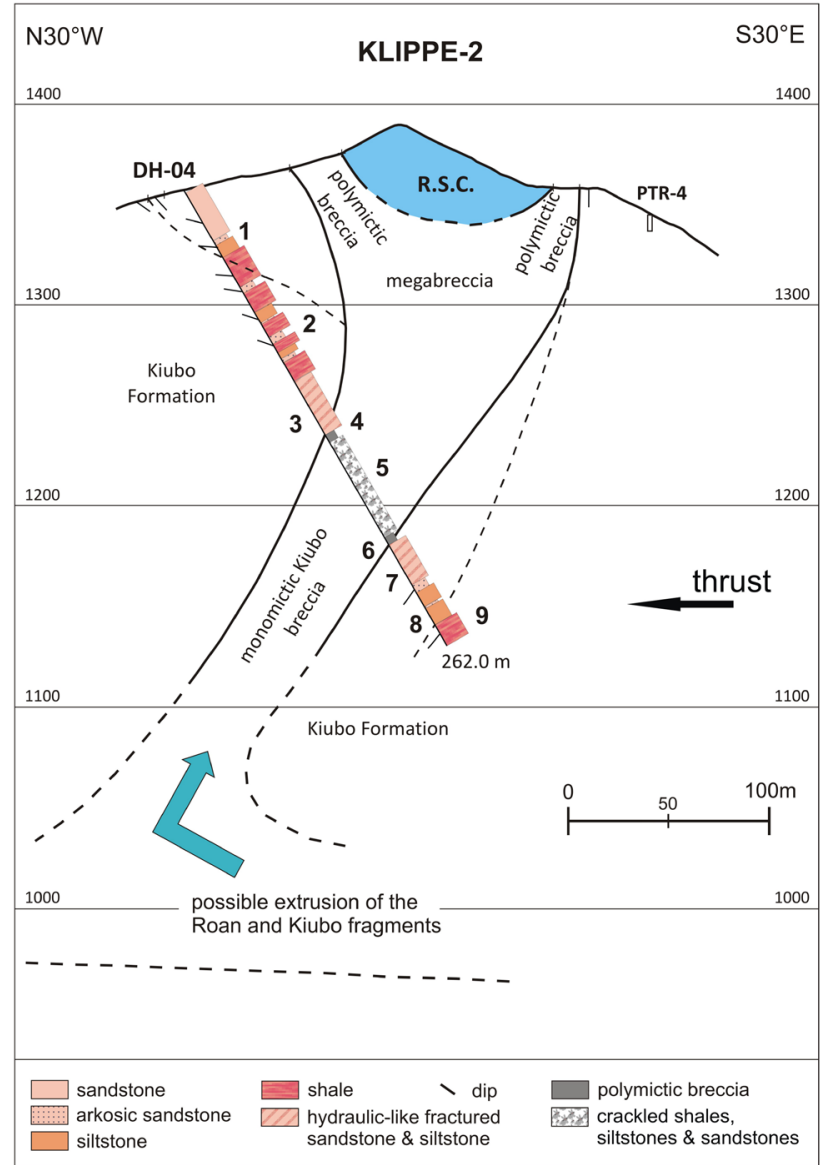

Figure 6. Cross section by the drill hole DH-04 through Klippe-2; structural and lithological data, geological interpretation; 1 to 9 see description in the text.

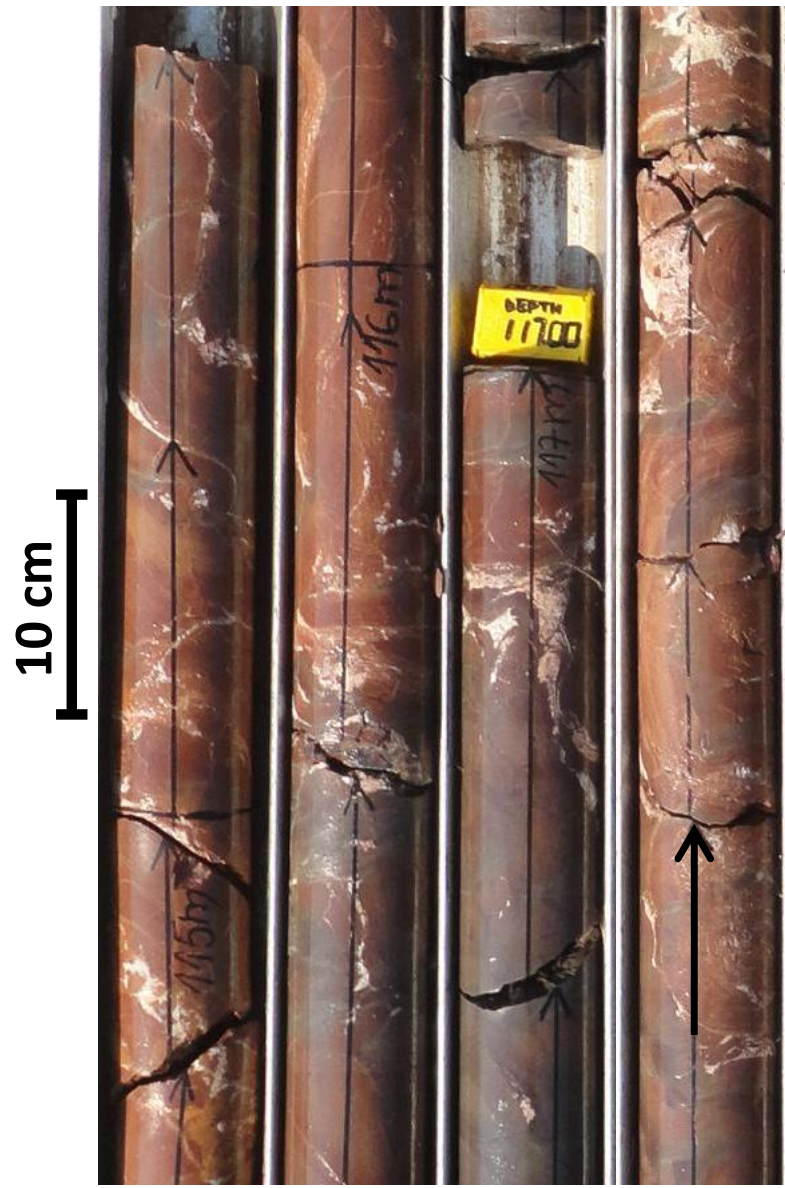

Figure 7. DH-04, cores between 115 and $118 \mathrm{~m}$ : hydraulic-like veinlets and ruptures in sandstones and sandy shales of the Kiubo Formation.
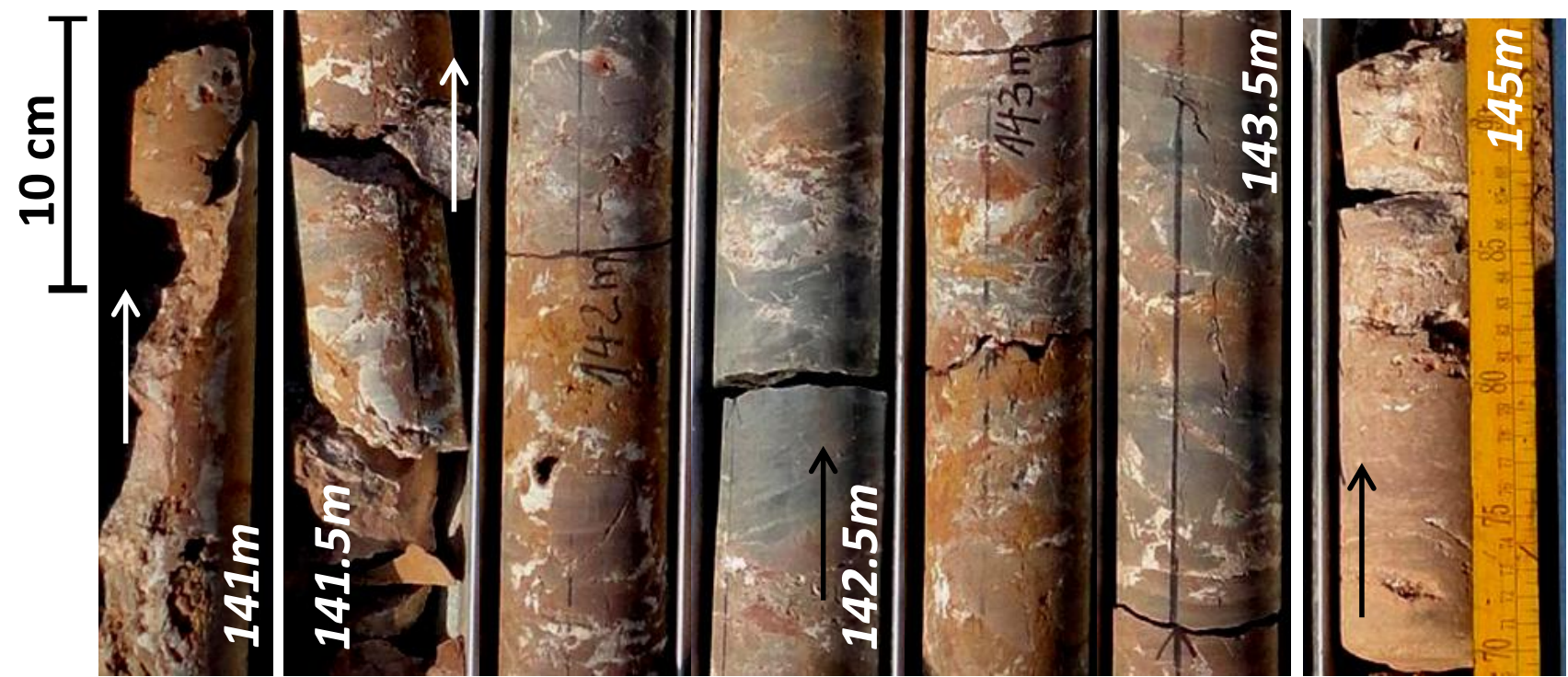

Figure 8. DH-04, cores between 141 and $145 \mathrm{~m}$; monomictic breccia composed of brecciated $\mathrm{cm}$ - to dm-size fragments of siltstones and arkosic sandstones, cemented by white and brownish carbonates, and marked by some cavities after dissolution of the carbonate.

The DH-04 drill hole performed from the northern ridge of Klippe-2, crosscut in depth breccia rocks and blocks of the Kiubo Formation between the same limbs that are bordering the megabreccia at the ground surface (Figs 4, 6). From surface to depth, the rocks succession comprises: (1) alternating, poorly fractured and veined, finely laminated siltstone, sandstone and arkosic sandstone beds; (2) predominant dark red shale beds in alternation with siltstone and arkosic sandstone beds, both 1 and 2 showing a low to medium dip that corresponds to the general gently dipping towards the south observed on the northern outcropping rocks at the ground surface; (3) a zone of the same alternating shale, siltstone and arkosic sandstone beds starting with a possible broken fault zone and with increasing amount of carbonate-filled hydraulic-like veinlets and ruptures as defined by Jébrak (1992) (Fig. 7); (4) a 4.4 m-thick monomictic breccia composed of brecciated $\mathrm{cm}$ - to dm-size fragments of sandy shales, siltstones and arkosic sandstones cemented by white and brownish carbonates, and marked by some dissolution texture within veins and as cavities (Fig. 8); some of the fragments clearly suggest rotation and jostling; (5) a crackle zone composed of purplish-red shale, muddy siltstone and arkosic sandstone disturbed packages with amount of carbonate-filled hydraulic-like veinlets, and 
ruptures, dissolution textures, and smooth plans or brecciation mostly observed in argillaceous shale suggesting shearing and friction; (6) a second $4 \mathrm{~m}$-thick possible monomictic breccia with only fragmented portion of cores recovered; (7) a zone similar to (3) mostly of alternating siltstone and arkosic sandstone beds with progressively decreasing carbonate-filled hydraulic-like veinlets and ruptures; (8) poorly fractured and veined siltstones and arkosic sandstones, with medium to high dips indicating a general high dipping towards the north, similarly as for the surface observations on the southern side of the klippe; (9) dark red shales chaotically bedded (recurrent internal refolding in various directions) probably due to soft sediment deformation. No Roan fragments (i.e. Mines, Musonoï) were observed in zones 4 to 6 that can be interpreted as a megabreccia.

Surface mapping identified several approximately north-south faults crosscutting the general orientation of the klippes, marked by relative displacements and thickness variations of the Kiubo beds and of the megabreccia (Fig. 4). This transverse faulting most likely occurs at the junction of the klippes, and clearly is the result of a tectonic event that postponed the formation of the klippes. They were probably a pathway for water circulation and supergene migration of copper from the klippes.

\section{Metallic mineralisation}

No significant occurrences of $\mathrm{Cu}-\mathrm{Co}$ mineralisation as carbonate, silicate or sulphide have been observed during the geochemical and surface exploration/mapping, especially in areas showing geochemical anomalies. Rocks of the megabreccias in the klippes, and especially the Kamoto Formation that commonly host the $\mathrm{Cu}-\mathrm{Co}$ mineralisation in the KCB (Cailteux et al., 2005), do not contain such occurrence and are oxidized by surface weathering. Hematite cubic relics suggest the presence mostly of euhedral pyrite prior to oxidation rather than $\mathrm{Cu}$ sulphides. No more than a very poor $\mathrm{Cu}$ sulphide mineralisation may have occurred in these rocks, as confirmed by the weakness of the related geochemical anomalies. Three core-drilling (DH-01, -02, -03) were performed in order to verify in depth the geochemical $\mathrm{Cu}-\mathrm{Co}$ anomalies observed in the southwest corner of the exploration permit (Fig. 3). The DH-02 and DH-03 are vertical holes (188.1 and 382.0 m-deep, respectively) crossing bedded carbonate shales and siltstones of the Kanianga Formation (Table 1). The DH-01 drilled at $90^{\circ} \mathrm{NE}$ with a $60^{\circ}$ inclination showed the following succession: (1) Kanianga alternating carbonate shales and siltstones; (2) Lusele pink carbonate rock (cap-carbonate) with a black Mn-rich clayish bed; (3) Kyandamu "Petit Conglomérat" diamictite; and (4) Monwezi sandstones (Table 1). These drill holes confirmed the local surface geology. No clear fractured zones and no $\mathrm{Cu}-\mathrm{Co}$ mineralisation were observed in depth. The DH-03 drilled in the area of the highest surface $\mathrm{Cu}$ anomaly in the extreme southwest corner of the license (Fig. 3) showed highest values between 1000-2000 ppm $\mathrm{Cu}$ and 250-750 ppm Co up to $5 \mathrm{~m}$-deep in the saprolite, suggesting contamination by surface water circulation.

\section{Interpretation and discussion}

Exploration in depth of Klippe-2 highlighted new major structural data. The rupture and brecciation of the Kiubo rocks, that are well observed in drill hole DH-04 below the ground surface megabreccia, showed: (1) hydraulic-like ruptures accompanied by precipitation of a carbonate cement in the voids and fractures of the rocks; and (2) fractured-deformed-brecciated rocks and friction breccias. As already demonstrated in the KCB (Cailteux et al., 2018), hydraulic-like ruptures indicate compression, fragmentation through expulsion of the fluids, and formation of ductile deformation and friction breccias related to the fold-andthrust event. Voids and cavities suggest dissolution of evaporitic material e.g. most likely contained within the Kiubo beds (François, 1973), while precipitation of the carbonate from the fluids followed decompression.

The deep faulted zone in Klippe-2 appears as the vertical extension of the megabreccia at the ground surface (Fig. 6), and most probably belongs to a major faulting and shearing extending along the axis of the five klippes (Figs 2,4). This faulting is supported by the differently dipping of on both sides of the fault of the Kiubo and Mongwe rocks succession, gently dipping to the south on the northern side and subvertically dipping to the north on the southern side (Fig. 6). The setting is comparable to this of the Kolwezi megabreccia where faulting of the Kundelungu Group rocks and monomictic breccias subvertically crosscut the underlying Kiubo Formation (Cailteux, 1991; Cailteux in François, 1994).

The rupture and shearing affecting the Kiubo Formation in depth, and the occurrence in the megabreccia of frequent Kiubo fragments or blocks teared out the limbs of the fault, suggest that the subvertical faulting in depth represents the root of the overlying megabreccia. This interpretation, as already discussed for Kolwezi (Cailteux, 1991; Cailteux in François, 1994; Cailteux et al, 2018), invalidates the hypothesis of the extrusion of the klippes megabreccias from the Kansuki fault over an autochthonous massif. Contrastingly, it suggests an extrusion of the megabreccias between the neighbouring blocks of the Nguba and Kundelungu groups during the fold-and-thrust event of the Katangan orogenesis, and a pinching out before suture of the blocks during the final stage of compression in that area. Compression at that final stage is supported by the sharp refolding of the Kiubo beds on the northern side, close to the klippes, and also by later transversal approximately north-south faulting and shearing through the megabreccias and the bordering Kiubo Formation.

A comparable setting has been described for several other megabreccias (e.g. Monwezi, south of the Kansuki fault, Fig. 2; Sesa, Kamatanda in the Likasi region and Kipushi in the Lubumbashi region, Fig. 1), that have been interpreted as diapiric extrusions from depth of Roan Group fragments between the two subvertical limbs of the fault (François, 1987, 1994; De Magnée \& François, 1988). Similarly, salt tectonics/diapirism has been evoked for the Kolwezi megabreccia in order to explain: (1) the stratigraphic inversion; and (2) the nearly concentric/symmetric lay out and opposite dip, on both parts of the axis of the megabreccia, for the Musonoï, Mines and Fungurume subgroups blocks (Placet, in Cailteux 1991). However, at the present stage of knowledge, despite some minor evaporitic material has been documented within some formations, they are no evidence of important masses of evaporites interbedded within the Katanga Supergroup prior to its deformation that could support a diapiric tectonism as proposed by De Magnée \& Francois (1988) and Jackson et al. (2003). Contrastingly, as demonstrated for most of the megabreccias in the KCB (Cailteux \& Kampunzu, 1995; Cailteux et al., 2018), compression-rupture-decompression during the fold-and-thrust event, and the fluidization within brecciated rocks associated to evaporitic solutions, contributed to the formation of megabreccias, transportation of the thrust nappes and injection of the megabreccias between the blocks of the nappes.

\section{Conclusion}

No occurrences of economic $\mathrm{Cu}-\mathrm{Co}$ mineralisation have been found during the surface exploration, mapping and drilling, especially in the klippes where the Roan megabreccia constituted a main target.

The lithologic and structural observations in the Five-Klippes area demonstrated that the Kiubo rocks are disrupted by a major subvertical faulting probably extending along the southwestnortheast oriented axis of the klippes. This faulting shows a similar orientation to this of the major thrust faults in that region (Fig. 2), and is interpreted to be related to the Lufilian fold-andthrust event (Kampunzu \& Cailteux, 1999; Kipata et al., 2013). The Five-Klippes megabreccias are most likely interpreted as pinched out between blocks of the Nguba-Kundelungu succession as a result of the northward compression during thrusting. A later transversal fracturing and shearing crosscutting the megabreccias and the bordering Kiubo Formation suggest differential approximately north-south readjustments at the end of the compression in that area. This setting can be compared to this of the Kolwezi megabreccia, and supports the hypothesis developed in previous studies that the Nguba and Kundelungu groups in this northwestern portion of the KCB could represent allochthonous terrains rather than an autochthonous massif, similarly as for the Mamfwe anticline slice. However, more data in this northwestern 
area is needed in order to complete the discussion.

\section{Acknowledgements}

The authors are grateful to the Vale-RDC Company for accessing to and using their exploration results. The authors are grateful to Denis Thiéblemont and an anonymous reviewer for their constructive reviews and suggestions that led to improve this paper significantly.

\section{References}

Batumike, M.J., Cailteux, J.L.H. \& Kampunzu, A.B., 2007. The Neoproterozoic Nguba and Kundelungu successions in the central African Copperbelt: lithostratigraphy, basin development and regional correlations. Gondwana Research, 11, 432-447. https://doi. org/10.1016/j.gr.2006.04.012

Cailteux, J., 1991. La tectonique intra-katanguienne dans la région NordOuest de l'Arc Lufilien (Shaba, Rép. du Zaïre). Annales de la Société Géologique de Belgique, 113 (1990), 199-215.

Cailteux, J., 1994. Lithostratigraphy of the Neoproterozoic Shaba type (Zaire) Roan Supergroup and metallogenesis of associated stratiform mineralization. In Kampunzu, A.B. \& Lubala, R.T. (eds), Neoproterozoic Belts of Zambia, Zaire and Namibia. Journal of African Earth Sciences, 19, 279-301. https://doi.org/10.1016/08995362(94)90015-9

Cailteux, J.L.H. \& De Putter, T., 2019. The Neoproterozoic Katanga Supergroup (D.R.Congo): State of the art and revisions of the lithostratigraphy, sedimentary basins and geodynamic evolution. Journal of African Earth Sciences, 150, 522-531. https://doi. org/10.1016/j.jafrearsci.2018.07.020

Cailteux, J. \& Kampunzu, A.B., 1995. The Katangan tectonic breccias in the Shaba province (Zaire) and their genetic significance. In Wendorff, M. \& Tack, L. (eds), Late Proterozoic Belts in Central Africa. Musée Royal de l'Afrique Centrale, Tervuren, Belgique. Annales des Sciences Géologiques, 101, 63-76.

Cailteux, J.L.H., Kampunzu, A.B., Lerouge, C., Kaputo, A.K. \& Milesi, J.P., 2005. Genesis of sediment-hosted stratiform copper-cobalt deposits, Central African Copperbelt. In Robb, L., Cailteux, J. \& Sutton, S. (eds), Recent advances in the geology and mineralization of the Central African Copperbelt. Journal of African Earth Sciences, 42, 134-158. https://doi.org/10.1016/j.jafrearsci.2005.08.001

Cailteux, J.L.H., Kampunzu, A.B. \& Lerouge, C., 2007. The Neoproterozoic Mwashya-Kansuki rock succession in the central African Copperbelt, its $\mathrm{Cu}-\mathrm{Co}$ mineralisation, and regional correlations. Gondwana Research, 11, 414-431. https://doi. org/10.1016/j.gr.2006.04.016

Cailteux, J.L.H., Muchez, Ph., De Cuyper, J., Dewaele, S. \& De Putter, Th., 2018. Origin of the megabreccias in the Katanga Copperbelt (D. R. Congo). Journal of African Earth Sciences, 140, 76-93. https:// doi.org/10.1016/j.jafrearsci.2017.12.029

Cosy, M., De Bonis, A., Gosso, G., Hunziker, J., Martinotti,G., Moratto, S., Robert, J.P. \& Ruhlman, F., 1992. Late Proterozoic thrust tectonics, high-pressure metamorphism and uranium mineralization in the Domes Area, Lufilian Arc, northwerstern Zambia Precambrian Research, 58, 215-240. https://doi.org/10.1016/03019268(92)90120-D

Coward, M.P. \& Daly, M.C., 1984. Crustal lineaments and shear zones in Africa: their relationship to plate movements. Precambrian Research, 24, 27-45. https://doi.org/10.1016/0301-9268(84)90068-8

De Magnée, I. \& François, A., 1988. The origin of the Kipushi $(\mathrm{Cu}, \mathrm{Zn}$, $\mathrm{Pb})$ deposit in direct relation with a Proterozoic salt diapir. Copperbelt of Central Africa, Shaba, Rep. of Zaire. In: Friedrich, G.H. and Herzig, P.M. (eds), Base metal Sulfide Deposits in Sedimentary and Volcanic Environments. Springer-Verlag, Berlin, 74-93. https://doi. org/10.1007/978-3-662-02538-3_5

El Desouky, H., Muchez, Ph., Boyce, A.J., Schneider, J., Cailteux, J., Dewaele, S. \& von Quadt, A, 2010. Genesis of sediment-hosted stratiform copper-cobalt mineralization at Luiswishi and Kamoto, Katanga Copperbelt (Democratic Republic of Congo). Mineralium Deposita, 45/8, 735-763. https://doi.org/10.1007/s00126-010-0298-3

François, A., 1973. L'extrémité occidentale de l'arc cuprifère shabien. Etude géologique. Bureau d'études géologiques, GécaminesExploitation, Likasi, Zaïre, 65 p.

François, A., 1987. Synthèse géologique sur l'arc cuprifère du Shaba (Rép. du Zaïre). Centenaire de la Société belge de Géologie, 15-65.

François, A., 1994. La structure tectonique du Katanguien dans la région de Kolwezi (Shaba, Rép. du Zaïre). Annales de la Société géologique de Belgique, 116 (1993), 87-104.

François, A., 1995. Le contact entre le socle kibarien et la couverture katanguienne dans la région de Kolwezi (Shaba, Zaïre). Bulletin de la Société belge de Géologie, 104, 3/4, 283-289.
François, A., 2006. La partie centrale de l'Arc cuprifère du Katanga: étude géologique. Tervuren African Geoscience Collection, 109, 61 p.

Jackson, M.P.A., Warin, O.N., Woad, G.M. \& Hudec, M.R., 2003. Neoproterozoic allochthonous salt tectonics during the Lufilian orogeny in the Katangan Copperbelt, central Africa. Geological Society of America Bulletin, 115, 314-330. https://doi. org/10.1130/0016-7606(2003)115<0314:NASTDT>2.0.CO;2

Jébrak, M., 1992. Les textures intra-filoniennes, marqueurs des conditions hydrauliques et tectoniques. Chroniques de la recherche Minière 506, 25-35.

Kampunzu, A.B., Kapenda, D. \& Manteka, B., 1991. Basic magmatism and geotectonic evolution of the Pan African belt in Central Africa: evidence from the Katangan and West Congolian segments. Tectonophysics, 190, 363-371. https://doi.org/10.1016/00401951(91)90438-X

Kampunzu, A.B. \& Cailteux, J., 1999. Tectonic evolution of the Lufilian arc (Central Africa Copperbelt) during the Neoproterozoic Panafrican orogenesis. Gondwana Research, 2, 401-421. https://doi. org/10.1016/S1342-937X(05)70279-3

Kennedy, K., Eyles, N., Broughton, D., 2019. Basinal setting and origin of thick $(1.8 \mathrm{~km})$ mass-flow dominated Grand Conglomérat diamictites, Kamoa, Democratic Republic of Congo: resolving climate and tectonic controls during Neoproterozoic glaciations. Sedimentology 66, 556-589. https://doi.org/10.1111/sed.12494

Kipata, M.L., Delvaux, D., Sebagenzi, M.N., Cailteux, J. \& Sintubin, M., 2013. Brittle tectonic and stress field evolution in the PanAfrican Lufilian Arc and its foreland (Katanga, DRC): from orogenic compression to extensional collapse, transpressional inversion and transition rifting. Geologica Belgica, 16, 1-17.
Manuscript received 15.07.2018, accepted in revised form 26.06.2019, available on line 28.10.2019. 